\title{
Mobility of heavy metals in soils amended with sewage sludge
}

\author{
M. T. Morera, J. C. Echeverría, and J. J. Garrido \\ Departamento de Química Aplicada. Universidad Pública de Navarra. Campus Arrosadía, E-31006 Pamplona. \\ Spain. E-mail: j.garrido@unavarra.es. Received 7 July 2000, accepted 30 April 2001.
}

\begin{abstract}
Morera, M. T., Echeverría, J. C. and Garrido, J. J. 2001. Mobility of heavy metals in soils amended with sewage sludge. Can. J. Soil Sci. 81: 405-414. Sewage sludges added to arable land can improve soil fertility and physical properties. However, the concentrations of heavy metals commonly found in sludges limits their application to soil. The purpose of this paper is to evaluate the mobility of heavy metals $(\mathrm{Cd}, \mathrm{Cu}, \mathrm{Ni}, \mathrm{Pb}$ and $\mathrm{Zn})$ in four soils amended with different rates $\left(0,80,60 \mathrm{and} 320 \mathrm{t} \mathrm{ha}^{-1}\right)$ of anaerobically stabilized urban sewage sludge. Total metal content in the sewage sludge was $\mathrm{Zn} \gg \mathrm{Cu}>\mathrm{Pb}>\mathrm{Ni} \gg \mathrm{Cd}$. Sludge, soils and sludge-soil mixtures were fractionated by the Tessier sequential extraction procedure. The fractions extracted by $\mathrm{H}_{2} \mathrm{O}_{2} / \mathrm{HNO}_{3}$ and $\mathrm{NH}_{2} \mathrm{OH} . \mathrm{HCl}$ were the most abundant pools for metals under study. The apparent mobility of metals in the sludge was $\mathrm{Zn} \approx \mathrm{Cd} \approx \mathrm{Ni}>\mathrm{Pb}>\mathrm{Cu}$. The addition of sewage sludge in soils increased the percentages of metal extracted in non-residual fractions. ANOVA showed that the most significant increases were those of $\mathrm{Zn}$, followed by $\mathrm{Cu}$ and $\mathrm{Pb}$; there were no statistical differences $(P<0.05)$ for $\mathrm{Ni}$ and $\mathrm{Cd}$. Exchangeable $\mathrm{Zn}$ from sludge was immobilized in basic soils. The other trace metals showed no fraction redistribution. The soils and sludge-treated soil samples were also extracted with EDTA and DTPA. Extraction with EDTA was more sensitive to soil type, whereas extraction with DTPA showed wider variation with metals. Both chelates seemed to be more effective to assess the mobility of metals added with the sludges at low concentrations than the Tessier's chemical partitioning.
\end{abstract}

Key words: Soils, sewage sludge, heavy metals, mobility

\begin{abstract}
Morera, M. T., Echeverría, J. C. et Garrido, J. J. 2001. Mobilité des métaux lourds dans les sols amendés avec des boues usées. Can. J. Soil Sci. 81: 405-414. L'addition de boues usées aux terres arables peut améliorer la fertilité et les propriétés physiques du sol. La concentration de métaux lourds dans les boues restreint toutefois une telle application. Les auteurs ont évalué la mobilité des métaux lourds $(\mathrm{Cd}, \mathrm{Cu}, \mathrm{Ni}, \mathrm{Pb}$ et $\mathrm{Zn})$ dans quatre sols auxquels avait été ajoutée une quantité variable $\left(0,80,60\right.$ et 320 t ha $\left.{ }^{-1}\right)$ de boues usées urbaines stabilisées en anaérobiose. La concentration totale de métaux dans la boue était de $\mathrm{Zn}$ >> $\mathrm{Cu}>\mathrm{Pb}>\mathrm{Ni}$ > Cd. La boue, le sol et le mélange sol-boue ont été fractionnés par la technique d'extraction séquentielle de Tessier. Les fractions obtenues par extraction dans $\mathrm{H}_{2} \mathrm{O}_{2} / \mathrm{HNO}_{3}$ et $\mathrm{NH}_{2} \mathrm{OH}$. $\mathrm{HCl}$ contenaient la plus grande quantité de métaux de toutes les fractions examinées. La mobilité apparente des métaux dans la boue correspond à $\mathrm{Zn} \approx \mathrm{Cd} \approx \mathrm{Ni}>\mathrm{Pb}>\mathrm{Cu}$. $\mathrm{L}$ 'addition de boues usées au sol augmente la proportion de métal extrait des fractions non résiduelles. L'analyse de la variance révèle que c'est la concentration de $\mathrm{Zn}$ qui connaît la hausse la plus importante, le $\mathrm{Cu}$ et le $\mathrm{Pb}$ arrivant en second; les auteurs n'ont relevé aucune variation statistiquement significative $(P<0,05)$ pour le Ni et le Cd. Les ions Zn échangeables présents dans la boue sont immobilisés dans les sols basiques. Il n'y a pas redistribution des autres métaux à l'état de trace dans les fractions. On a aussi extrait les métaux présents dans le sol et le mélange sol-boue avec de l'EDTA et du DTPA. L'extraction à l'EDTA varie plus avec le type de sol tandis que celle au DTPA varie plus avec le métal. Les deux chélates semblent donner de meilleurs résultats que la méthode de fractionnement chimique de Tessier quand il s'agit d'évaluer la mobilité des métaux en faible concentration dans les boues.
\end{abstract}

Mots clés: Sols, boues usées, métaux lourds, mobilité

The use of sewage sludge as an organic amendment in agriculture is a widespread practice in many countries. Sewage sludges disposed of on arable land improve the fertility and physical properties of the soil. However, the high concentrations of heavy metals, commonly found in sludges, limit their application on land (Alloway 1995). Mobility, environmental diffusion and bioavailability of heavy metals present in the sewage sludge largely depend on soil physico-chemical characteristics and, likewise, on trace metal chemical forms (Obrador et al. 1998).

Several soil-related factors, namely $\mathrm{pH}$, organic matter, Mn and Fe oxides, and clay content determine the chemical associations of heavy metals and their availability to plants (Narwal and Singh 1998). Among these factors, $\mathrm{pH}$ has been regarded as a major variable regulating the metal mobility in soils (Heckman et al. 1987). The sorption and the precipitation of heavy metals are enhanced by increasing soil pH (Kiekens 1984; Alloway and Jackson 1991). These processes help to explain the decreased mobility normally found in soils with a basic $\mathrm{pH}$.

Sequential extractions have been used to fractionate heavy metals in sludge (McGrath and Cegarra 1992; Petruzzelli et al. 1994) or sludge-amended soils to investigate their chemical distribution among the solid fractions 
(Emmerich et al. 1982; McGrath and Cegarra 1992) and, indirectly, their mobility and plant availability (Dudka and Chlopecka 1990; Sims and Kline 1991; Tsadilas et al. 1995). Despite uncertainties related to the selectivity of the various extractants and to potential problems due to readsorption, sequential extraction procedures provide detailed information about the status of trace metals in soils (Pickering 1986; Echeverría et al. 1998). A procedure used extensively in soils and sediments is that of Tessier et al. (1979), which is based on five operationally defined fractions: exchangeable, carbonate, Fe-Mn oxides, organic, and residual. The exchangeable fraction is considered to be the most plant-available form (Petruzzelli 1989; Xian and Shokohifard 1989; Shuman 1991), whereas metals extracted in the residual fraction are considered to be less mobile and available in the short to a medium term (Brümer 1986). Application of sewage sludge to soil may alter heavy metal content in the fractions and enhance chemical forms potentially available (Pengxing et al. 1997).

Single chemical extractions with synthetic chelating agents such as ethylene diamine tetraacetic acid (EDTA) and diethylene triamine pentaacetic acid (DTPA) have been widely used to study relationships between metals in plants and soils. Single extractions are less time consuming than sequential extractions. They have been used as an alternative to sequential extractions in routine tests to evaluate plant availability and mobility of heavy metals in soils amended with sewage sludge (Lebourg et al. 1996). These extractants usually aim to extract the fractions that are water-soluble, easily exchangeable, and some of the organic bound metals, although they can also dissolve some of the carbonates and oxyhydroxides (Pickering 1986). The efficiency of these extractants is usually measured in terms of their ability to extract an amount of metal that correlates well with the plant content. Correlations vary according to the analyzed metal, soil and experimental conditions (Kuo 1990; Juste and Tauzin 1992). The metal ions extracted are not necessarily the same as the ions absorbed by the plant. They are only related by a satisfactory empirical relationship allowing for a rough prediction of the mobility of the metal.

The purpose of this study was to investigate the mobility of sludge-borne heavy metals added to four soils with different physico-chemical properties. In order to enhance these effects, sewage sludge was applied at rates $(80,160$ and $320 \mathrm{t} \mathrm{ha}^{-1}$ ) up to the maximum limit values established by the Spanish (R.D. 13110/1990) and European Community (86/278/EEC). Trace elements were sequentially extracted using the Tessier procedure from sludge, soils and sludge-treated soil samples. The soils and sludge-treated soil samples were also extracted with two solutions standardized for predicting plant availability, which include EDTA (pH 4.65) and DTPA (pH 7.30).

\section{MATERIALS AND METHODS}

\section{Soils and Sewage Sludge}

The four soil samples used in this study were collected in Navarra (Spain). According to soil taxonomy (Soil Survey
Staff 1975), the soils were Lithic Haplumbrept (Lh), Calcixerollic Xerochrept ( $\mathrm{Cx} 1$ and $\mathrm{Cx} 2)$, and Paralithic Xerorthent (Px). Calcixerollic Xerochrepts (Cx1 and Cx2) and Px were agricultural soils, whereas Lh was uncultivated (Echeverría et al. 1998, 1999a). Samples from the top $15 \mathrm{~cm}$ soil layer were air-dried, ground, and sieved through a 2-mm mesh before determining specifics soils properties: (1) particle-size distribution by fractionation using wet sieving and sedimentation (Primo Yúfera and Carrasco Dorriens 1987); (2) mineralogical composition of clay fraction by a Siemens D500 X-ray diffractometer; (3) total amount of carbon and nitrogen by using a Carlo Erba EA 1108 elemental analyzer; (4) inorganic carbon (Loeppert et al. 1984); (5) $\mathrm{pH}$ (McLean 1982); (6) cation-exchange capacity (CEC) by $\mathrm{Ca}^{2+}$ saturation, displacement by $1 \mathrm{M}$ sodium acetate and measurement of $\mathrm{Ca}^{2+}$ ions by atomic absorption spectroscopy (Jackson 1982); and (7) surface area by $\mathrm{N}_{2}$ gas adsorption at $77 \mathrm{~K}$ (Echeverría et al. 1999b). Selected physical and chemical characteristics of soils are presented in Table 1. With the exception of the Lh soil, which is acidic and has a large organic $\mathrm{C}$ content, the other three soils had a basic $\mathrm{pH}$, and contained a moderate or small percentage of organic $\mathrm{C}$. The CEC values were similar to those found in references for illite (10-40 meq $100 \mathrm{~g}^{-1}$ ) (Tan 1982; Alloway 1990), which was the most abundant phyllosilicate in soils under study. The BET surface area obtained from $\mathrm{N}_{2}$ adsorption at $77 \mathrm{~K}$ of the soils ranged from $8 \mathrm{~m}^{2} \mathrm{~g}^{-1}$ for $\mathrm{Lh}$ to $50 \mathrm{~m}^{2} \mathrm{~g}^{-1}$ for $\mathrm{Cx} 1$.

The sludge was collected from the wastewater treatment plant of Arazuri that receives domestic and industrial water from Pamplona (Spain). It was a primary anaerobically digested sludge. Chemical properties of sewage sludge and total concentration, of $\mathrm{Cd}, \mathrm{Cu}, \mathrm{Ni}, \mathrm{Pb}$ and $\mathrm{Zn}$ are presented in Table 2. The largest concentration was that of $\mathrm{Zn}$ followed by $\mathrm{Cu}, \mathrm{Pb}, \mathrm{Ni}$ and $\mathrm{Cd}$. These concentrations are usually found in sludges with low inputs in industrial sewage, and were far below the Spanish and European Community limit values for agricultural use.

\section{Soils Treatment with Sewage Sludge}

Subsamples of each air-dried sieved $(<2 \mathrm{~mm})$ soil were thoroughly mixed with the air-dried ground homogenized sludge in pots to produce mixtures equivalent in the field to application rates of 0 (reference), 80, 160 and $320 \mathrm{t} \mathrm{ha}^{-1}$. Assuming an incorporation depth of $30 \mathrm{~cm}$, the doses of sewage sludge, equivalent to $0,80,160$ and $320 \mathrm{t} \mathrm{ha}^{-1}$ were 0 ; 0.027; 0.053; and $0.107 \mathrm{~g}$ dry weight $\mathrm{cm}^{-3}$, respectively. These high application rates were an extreme treatment that would not be recommended in agricultural practice. Considering the concentration of metals in the sewage sludge, an annual dose of $80 \mathrm{t} \mathrm{ha}^{-1}$ would be higher than the annual threshold for $\mathrm{Zn}$ according to Spanish and CEE regulations for the use of sewage sludge as soil amendment. The maximum amount of sewage sludge that could be added to the soils without going beyond the annual limit for $\mathrm{Zn}$ would be $56 \mathrm{t} \mathrm{ha}^{-1}$. The soil-sludge samples were left to settle at field temperature for a month by periodically adding distilled water to keep moisture near field capacity. For each treatment, an integrated sample was prepared by mixing 


\begin{tabular}{|c|c|c|c|c|}
\hline & $\begin{array}{l}\text { Lithic } \\
\text { haplumbrept } \\
\text { (Lh) }\end{array}$ & $\begin{array}{l}\text { Calcixerollic } \\
\text { xerochrept } \\
(\mathrm{Cx} 1)\end{array}$ & $\begin{array}{c}\text { Calcixerollic } \\
\text { xerochrept } \\
(\mathrm{Cx} 2)\end{array}$ & $\begin{array}{l}\text { Paralithic } \\
\text { xerorthent } \\
\quad(\mathrm{Px})\end{array}$ \\
\hline \multicolumn{5}{|l|}{ Particle size $\left(\mathrm{g} \mathrm{kg}^{-1}\right)$} \\
\hline$>50(\mu \mathrm{m})$ & 361 & 215 & 499 & 27 \\
\hline $50-2(\mu \mathrm{m})$ & 408 & 410 & 291 & 579 \\
\hline$<2(\mu \mathrm{m})$ & 231 & 375 & 210 & 394 \\
\hline Textural class & Loam & Clay loam & Loam & Silty clay \\
\hline Main clay minerals $\mathbf{z}$ & I & I & $\mathrm{M}, \mathrm{C}, \mathrm{I}$ & $\mathrm{I}$ \\
\hline Total C $\left(\mathrm{g} \mathrm{kg}^{-1}\right)$ & 108 & 15 & 45 & 56 \\
\hline Inorganic $\mathrm{C}\left(\mathrm{g} \mathrm{kg}^{-1}\right)$ & 2 & 7 & 23 & 51 \\
\hline Organic $C^{\mathbf{y}}\left(\mathrm{g} \mathrm{kg}^{-1}\right)$ & 106 & 8 & 22 & 5 \\
\hline Total $\mathrm{N}\left(\mathrm{g} \mathrm{kg}^{-1}\right)$ & 4.5 & 2 & 1.3 & 1.8 \\
\hline $\mathrm{pH}$ (saturated paste) & 5 & 7.2 & 7.9 & 8.1 \\
\hline Cationic exchange capacity (meq $100 \mathrm{~g}^{-1}$ ) & 17.3 & 23.9 & 10.7 & 14.8 \\
\hline Surface area $(B E T)^{\mathbf{x}}\left(\mathrm{m}^{2} \mathrm{~g}^{-1}\right)$ & 8 & 50 & 30 & 25 \\
\hline
\end{tabular}

$\mathrm{z}_{\mathrm{I}}=$ illite, $\mathrm{M}=$ montmorillonite, $\mathrm{C}=$ chlorite.

yobtained by difference.

${ }^{\mathbf{x}}$ Adsorption of $\mathrm{N}_{2}$ at $77 \mathrm{~K}$.

\begin{tabular}{lr}
\hline Table 2. Chemical characteristics of sewage sludge & \\
\hline $\mathrm{pH}$ & 7.3 \\
$\mathrm{C} / \mathrm{N}$ rate & 10.5 \\
Dry matter (\%) & 31.7
\end{tabular}

\begin{tabular}{|c|c|}
\hline \multicolumn{2}{|c|}{ Fertilizing elements (\%) } \\
\hline Organic carbon & 22.6 \\
\hline Inorganic carbon & 0.5 \\
\hline Total nitrogen & 2.2 \\
\hline Potassium $\left(\mathrm{K}_{2} \mathrm{O}\right)$ & 0.2 \\
\hline Phosphorous $\left(\mathrm{P}_{2} \mathrm{O}_{5}\right)$ & 3.5 \\
\hline \multicolumn{2}{|c|}{ Heavy metals ( $m g \mathrm{~kg}^{-1}$ dry weight) } \\
\hline $\mathrm{Cd}$ & 3 \\
\hline $\mathrm{Cu}$ & 325 \\
\hline $\mathrm{Ni}$ & 95 \\
\hline $\mathrm{Pb}$ & 201 \\
\hline $\mathrm{Zn}$ & 1503 \\
\hline
\end{tabular}

three portions taken from the surface, middle and bottom parts of the pots. These integrated samples were air-dried and crushed again to pass a $2-\mathrm{mm}$ sieve prior to determining $\mathrm{pH}$ and studying the mobility of heavy metals by chemical extractions. Amendment with sewage sludge increased $\mathrm{pH}$ of Lh soil by one unit after the application of $320 \mathrm{t}$ of sewage sludge ha ${ }^{-1}$, but did not alter the $\mathrm{pH}$ of alkaline soils (Cx1, Cx2 y Px).

\section{Metal Extraction Experiments}

The metal distribution in sewage sludge and soil sub-samples from each treatment was assessed by the sequential extraction procedure of Tessier et al. (1979). The steps in the sequence were operationally defined in terms of the targeted forms as follows (Kim and Fergusson 1991): Fraction 1 , exchangeable-weakly sorbed ( $8 \mathrm{~mL}, 1 \mathrm{M} \mathrm{MgCl} 2)$; Fraction 2, sorbed and/or carbonate bound $(8 \mathrm{~mL}, 1 \mathrm{M}$ $\mathrm{NaOAc/HOAc}$, pH 5.0); Fraction 3, strongly sorbed to organic matter and/or strongly bound to easily reducible manganese oxides and amorphous iron oxides $(20 \mathrm{~mL}$, $0.04 \mathrm{M} \mathrm{NH}_{2} \mathrm{OH} . \mathrm{HCl}$ in $25 \%$ acetic acid); Fraction 4, very strongly bound or incorporated into organic matter or other oxidizable species $\left(8 \mathrm{~mL}, \mathrm{H}_{2} \mathrm{O}_{2} 30 \%+3 \mathrm{~mL}, 0.02 \mathrm{M}\right.$ $\mathrm{HNO}_{3}$ ); Fraction 5, incorporated within resistant minerals $\left(20 \mathrm{~mL}, \mathrm{HF} 40 \%+4 \mathrm{~mL}, \mathrm{HClO}_{4} 70 \%\right)$. Suspensions were centrifuged at $3000 \mathrm{rpm}$ for $10 \mathrm{~min}$. Aliquots from the supernatants were removed, diluted up to $50 \mathrm{~mL}$ with distilled-deionized water and stored in polyethylene bottles to which $0.10 \mathrm{~mL}$ of $\mathrm{HNO}_{3}(70 \%)$ were added for sample preservation. The rest of the extract was discarded and the residue was washed with $8 \mathrm{~mL}$ of distilled-deionized water; after centrifugation, the wash solution was discarded.

Extractable metal concentrations in soil subsamples from each treatment were also determined using EDTA and DTPA. In the EDTA extraction (Lakanen and Erviö 1971), $3 \mathrm{~g}$ of soil were extracted with $30 \mathrm{~mL}$ of $0.02 \mathrm{M}$ EDTA + $0.5 \mathrm{M} \mathrm{NH}_{4} \mathrm{OAc}(\mathrm{pH} 4.65)$ for $1 \mathrm{~h}$. In the DTPA extraction (Lindsay and Norvell 1978) $15 \mathrm{~g}$ of soil were extracted with $30 \mathrm{~mL}$ of $0.005 \mathrm{M}$ DTPA + 0.1 M TEA (trietanolamine) + $0.01 \mathrm{M} \mathrm{CaCl}_{2}(\mathrm{pH} 7.30)$ for $2 \mathrm{~h}$. The suspensions were placed in a thermostated water bath (Grant model SS40-2) at $298.0 \pm 0.2 \mathrm{~K}$, and shaken at $3 \mathrm{~Hz}$. After the specified time for each extraction, suspensions were centrifuged at 3000 rpm for $10 \mathrm{~min}$ and the supernatants, acidified with $0.10 \mathrm{~mL}$ of $\mathrm{HNO}_{3}(70 \%)$, were stored in polyethylene bottles for metal determination.

For each sample, sequential extraction and extractions with EDTA and DTPA were conducted in triplicate. Standards for all metals analyzed were prepared for each extraction in the same matrix as the extracting reagent to minimize matrix effects. Metal concentrations were determined by atomic absorption spectrophotometry (PerkinElmer mod. 2100). To determine total metal concentration in soils and sewage sludge triplicate sub-samples ( $1 \mathrm{~g}$ dry $\mathrm{wt}$ ) were digested using the same procedure as that used for the residual fraction (Tessier et al. 1979).

\section{Statistical Analysis}

Sewage sludge treatment effects on content and mobility of heavy metals in soils were analyzed using variance analyses (ANOVA) based upon a design with three replications 


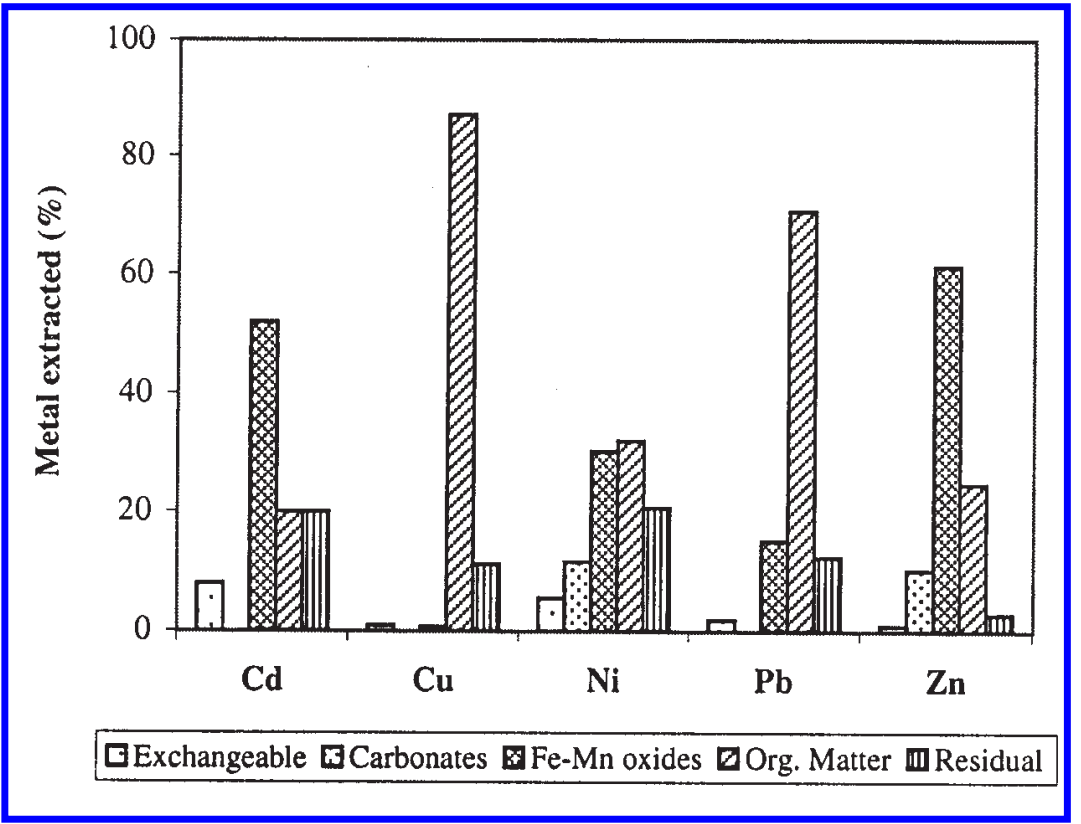

Fig. 1. Mean percentages of $\mathrm{Cd}, \mathrm{Cu}, \mathrm{Ni}, \mathrm{Pb}$ and $\mathrm{Zn}$ in the Tessier partitioning of sewage sludge.

(Winer et al. 1991). A probability level of $P<0.05$ was selected to establish statistical significance. We applied a multifactorial ANOVA to the percentages obtained from the Tessier fractions to evaluate the contribution to the total variance of sewage sludge rates $\left(0,80,160,320 \mathrm{tha}^{-1}\right)$, metals (Cd, Cu, Ni, Pb and $\mathrm{Zn}$ ), soils (Cx1, Cx2, Px and Lh) and fractions (exchangeable, carbonates, oxides and organic matter). Similarly, we applied a multifactorial ANOVA to the percentages of metals extracted with EDTA and DTPA, including sewage sludge rates, metals and soils. SPSS Advanced Statistics 6.1 was used for this purpose.

\section{RESULTS AND DISCUSSION}

\section{Heavy Metal Distribution in Sewage Sludge}

Figure 1 shows, in percentages, the distribution of the chemical forms of $\mathrm{Cd}, \mathrm{Cu}, \mathrm{Ni}, \mathrm{Pb}$ and $\mathrm{Zn}$ in the sewage sludge. The total percentage recoveries of metals extracted were $\mathrm{Cd}$, 100; $\mathrm{Cu}, 99 ; \mathrm{Ni}, 102 ; \mathrm{Pb}, 91$; and $\mathrm{Zn}, 93$. The Fig. 1 reflects the predominance of the fractions extracted by $\mathrm{H}_{2} \mathrm{O}_{2} / \mathrm{HNO}_{3}$ (organic matter) and $\mathrm{NH}_{2} \mathrm{OH} . \mathrm{HCl}$ (Fe and $\mathrm{Mn}$ oxides), with some differences among the metals. Copper and $\mathrm{Pb}$ were extracted mainly by $\mathrm{H}_{2} \mathrm{O}_{2} / \mathrm{HNO}_{3}(87.2 \%$ and $70.6 \%$, respectively); these results are consistent with the known affinity of copper and lead for organic ligands (Taylor et al. 1995). Copper appeared in somewhat more resistant chemical forms than $\mathrm{Pb}$, since percentage of these metals released by $\mathrm{NH}_{2} \mathrm{OH} . \mathrm{HCl}$ were $0.7 \%$ for $\mathrm{Cu}$ and 15.1 for $\mathrm{Pb}$. However, most of the $\mathrm{Zn}$ and $\mathrm{Cd}$ were extracted with hydroxylamine hydrochloride $(61.3 \%$ and $52 \%$, respectively). The findings for $\mathrm{Ni}$ were somewhere in between the other two groups, with similar percentages for $\mathrm{H}_{2} \mathrm{O}_{2} / \mathrm{HNO}_{3}$ $(32 \%)$ and $\mathrm{NH}_{2} \mathrm{OH} . \mathrm{HCl}(30.3 \%)$ fractions. More than $10 \%$ of $\mathrm{Ni}, \mathrm{Zn}$ and $\mathrm{Cd}$ were found in easily mobilizable forms (exchangeable and $\mathrm{NaOAc} / \mathrm{HOAc}$ extracted). Bearing in mind that fractions are extracted according to a gradient of association stability with the solid phases (Martin et al. 1987), and that extractability decreases roughly according to the order of extraction (Harrison 1981); mobility of metals in the sludge was as follows: $\mathrm{Zn} \approx \mathrm{Cd} \approx \mathrm{Ni}>\mathrm{Pb}>\mathrm{Cu}$.

Since the sum of the amounts of $\mathrm{Cd}, \mathrm{Cu}, \mathrm{Ni}, \mathrm{Pb}$ and $\mathrm{Zn}$ extracted by $\mathrm{NH}_{2} \mathrm{OH} . \mathrm{HCl}\left(918 \mathrm{mg} \mathrm{kg}^{-1}\right)$ was larger than the total $\mathrm{Fe}$ and $\mathrm{Mn}$ content released in that fraction $(881 \mathrm{mg}$ $\mathrm{kg}^{-1}$ ), it is highly unlikely that the metals extracted in this fraction were exclusively associated with $\mathrm{Fe}$ and Mn oxides. According to Kim and Fergusson (1991) some of the metals released in the oxide fraction are metals strongly sorbed to organic matter which were not extracted in previous fractions. Therefore, partitioning would reflect not only the contribution of geochemical phases, but also the diversity of reactive groups generated by the variety of active functional groups found in sludge organic matter and the different reactivity of metals.

\section{Effects of Sewage Sludge Application on Total Content and Distribution of Heavy Metals in Soils}

Total concentration of $\mathrm{Cd}, \mathrm{Cu}, \mathrm{Ni}, \mathrm{Pb}$ and $\mathrm{Zn}$ in soils following application rates of 0 (reference), 80, 160 and $320 \mathrm{t}$ $\mathrm{ha}^{-1}$ of sewage sludge are included in Fig. 2. In control soils $\left(0 \mathrm{t} \mathrm{ha}^{-1}\right)$ the total concentration of heavy metals was within the range of the most frequent values for natural soils (Adriano 1986; Kabata-Pendias and Pendias 1993). In general, the largest concentration corresponded to Lh, a soil derived from ophites. Amendment with sewage sludge increased the total concentration of $\mathrm{Cu}, \mathrm{Pb}$ and $\mathrm{Zn}$ in soils. The rise reflected the sludge metallic content (Table 2) and the doses applied. The biggest increases corresponded to $\mathrm{Zn}$, followed by $\mathrm{Cu}$ and $\mathrm{Pb}$; there were no significant differences $(P<0.05)$ in the total concentration of $\mathrm{Ni}$ and $\mathrm{Cd}$ after the addition of sludge.

The metal distribution in the five fractions of the Tessier procedure corresponding to the sewage sludge-amended 

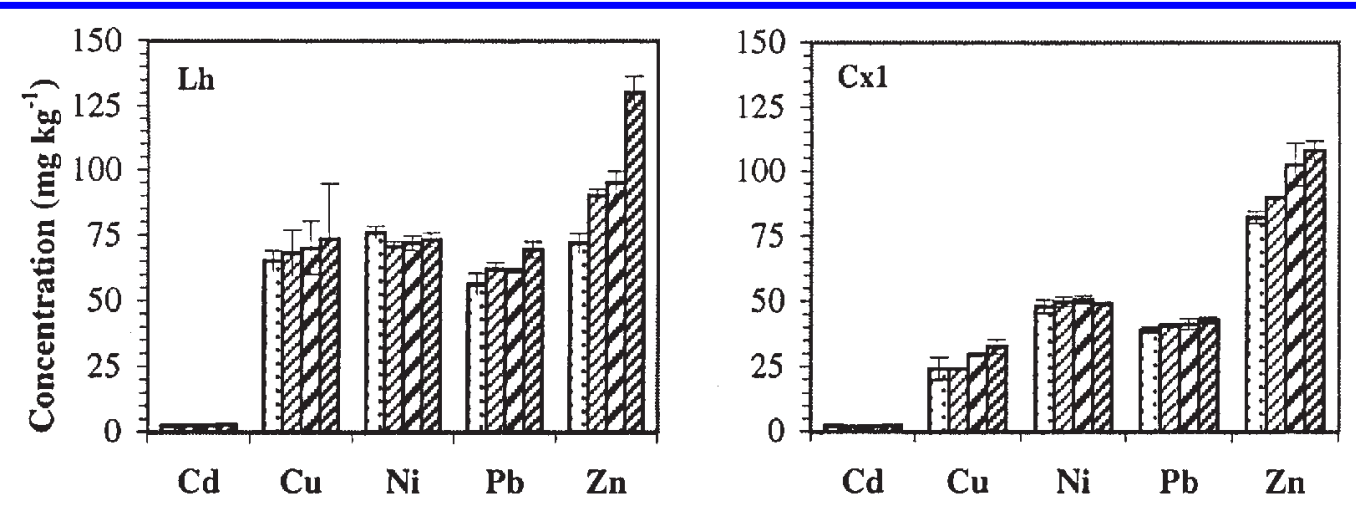

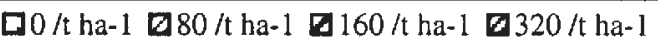
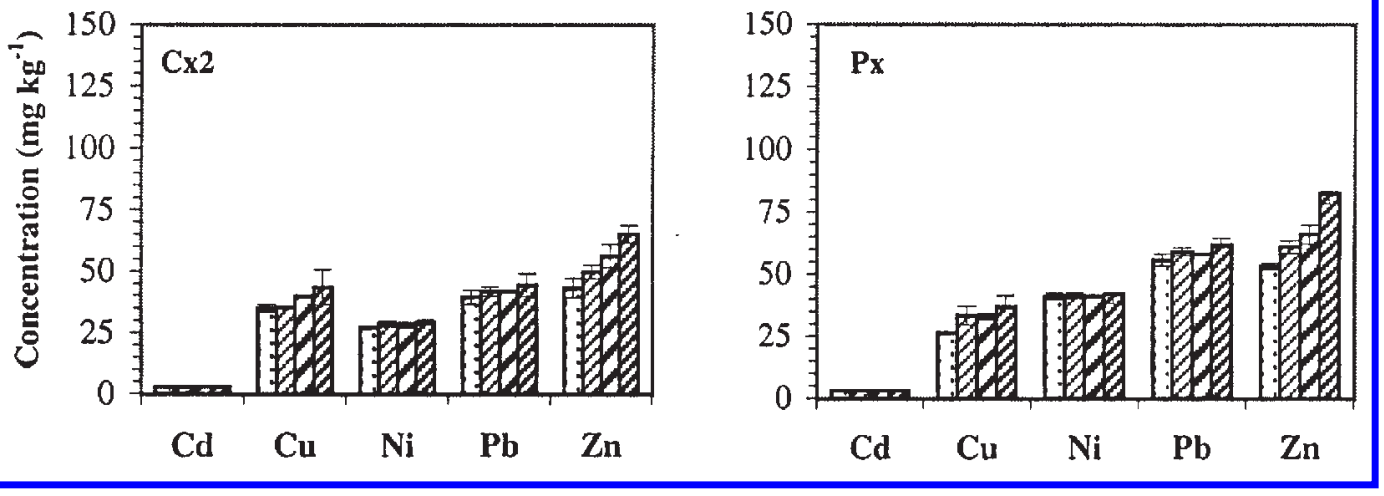

Fig. 2. Total concentration of metals in soils amended with sewage sludge. The results are the average concentration of three replicates and include the standard deviation.

soils differed according to the application rates, the metal extracted, and soil considered. On applying a multifactorial analysis of variance to all results, a positive correlation $\left(r^{2}=\right.$ 0.91 ) was detected between sludge application rate and the overall mean percentage of metals extracted in non residual fractions, ranging from $35.4 \%$ for $0 \mathrm{t} \mathrm{ha}^{-1}$ dose to $43.3 \%$ for $320 \mathrm{t} \mathrm{ha}^{-1}$ (Table 3). The application of sewage sludge provided a source of heavy metals and enriched the soils in relatively mobile and available forms (Pengxing et al. 1997). The mean percentages released in the non-residuals fractions, including the results of the four soils and five metals, showed greater rises for $\mathrm{NH}_{2} \mathrm{OH} . \mathrm{HCl}, \mathrm{H}_{2} \mathrm{O}_{2} / \mathrm{HNO}_{3}$, and $\mathrm{NaOAc} / \mathrm{HOAc}$ extractions than for exchangeable fraction (Table 3). The dissolution and consequently the mobility and bioavailability of metals added with sewage sludge are controlled mainly by organic matter and oxides that act as principal adsorbents and can prevent excessive mobilisation of heavy metals (McBride 1995). Soil carbonates decrease the availability of metals more for their effect on soil $\mathrm{pH}$ than for their adsorption capacity.

Table 3 shows that the increase in the overall mean percentage for metals extracted in the non residual fractions was brought about by $\mathrm{Zn}, \mathrm{Cu}$ and $\mathrm{Pb}$, but not by $\mathrm{Ni}$ and $\mathrm{Cd}$, which is consistent with the metal level in the sewage sludge. The effect of the application doses on the four soils
Table 3. Mean percentages of metals extracted in the non residual fractions following different sewage doses

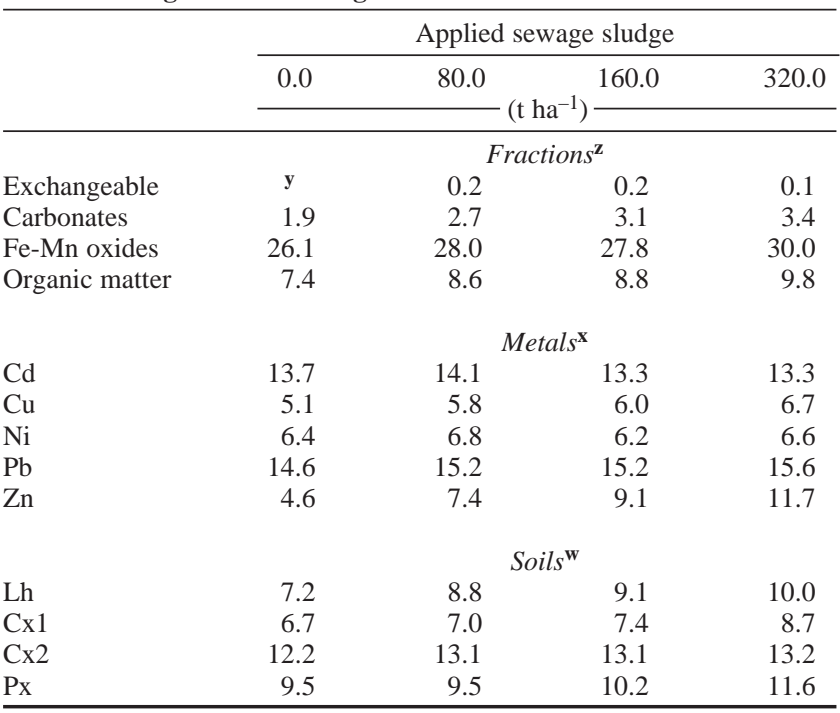

${ }^{\mathbf{z}}$ Average values including all studied metals and soils.

$\mathbf{y}_{\text {No detected. }}$

${ }^{\mathbf{x}}$ Average percentages extracted in the four non residual fractions of the four soils.

wAverage percentages extracted in the four non residual fractions of the five metals. 

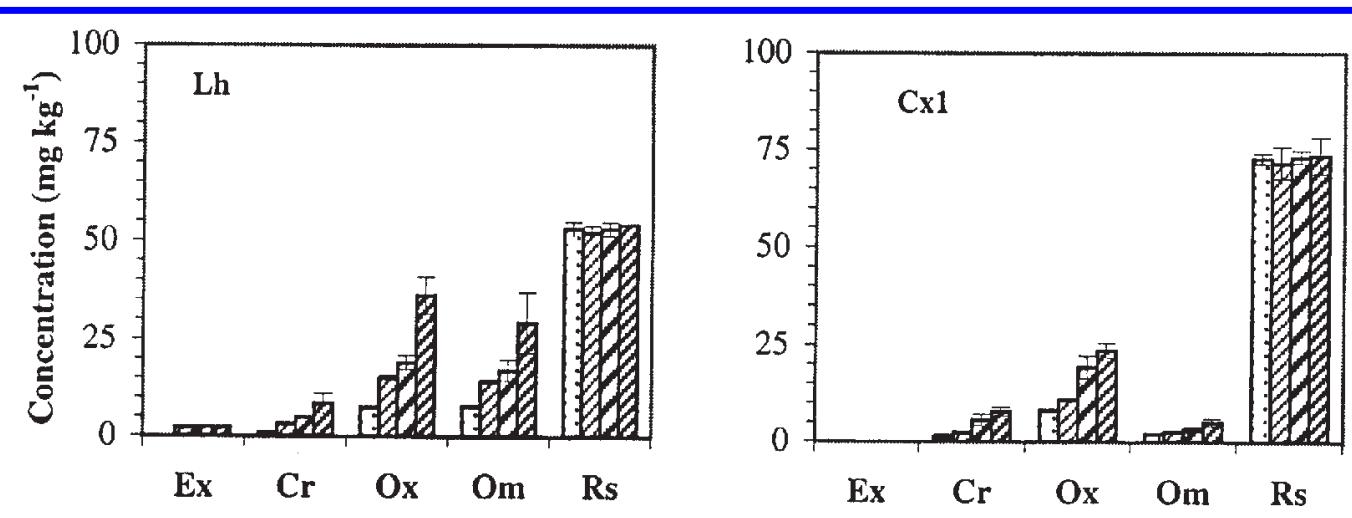

$\square 0 /$ ha-1 $\square 80 /$ ha-1 $\square 160 /$ ha-1 $\square 320 / t$ ha-1
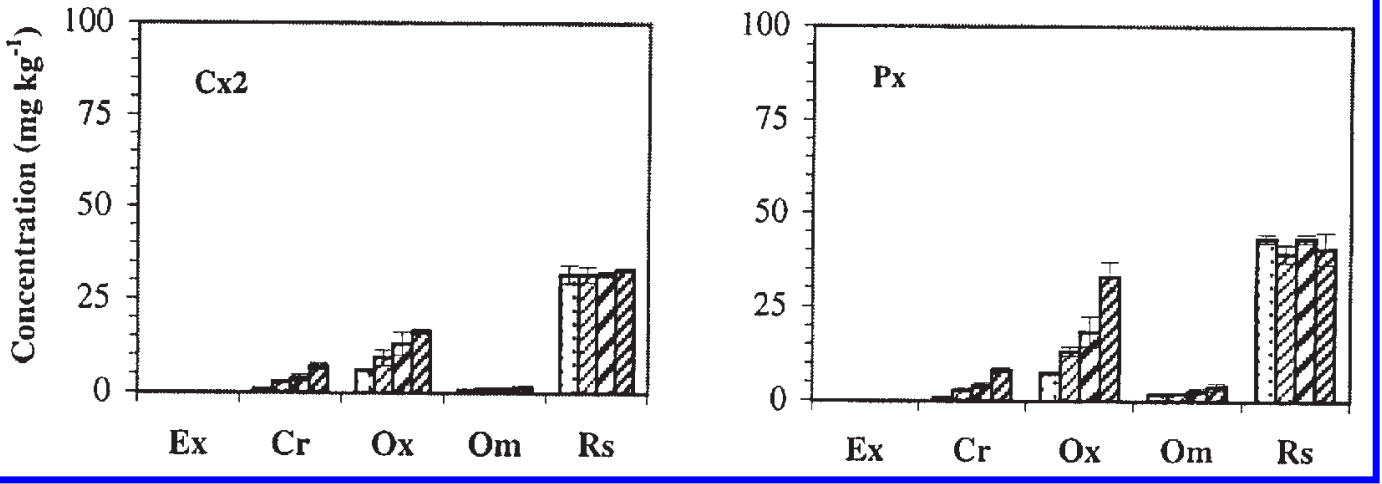

Fig. 3. Fractionation of $\mathrm{Zn}$ in the soils amended with sewage sludge $(0$, 80,160 and $320 \mathrm{t} \mathrm{ha}^{-1}$ ). The results are the average concentration of three replicates and include the standard deviation. (Ex, exchangeable; $\mathrm{Cr}$, carbonates; $\mathrm{Ox}, \mathrm{Fe}$ and $\mathrm{Mn}$ oxides; Om, organic matter; Rs, residual).

was slightly higher in the Lh soil than in the other three (Cx1, Cx2 and Px) because the apparent density of the Lh $\left(0.58 \mathrm{~g} \mathrm{~cm}^{-3}\right)$ was lower than that of Cx1 $\left(1.05 \mathrm{~g} \mathrm{~cm}^{-3}\right), \mathrm{Cx} 2$ $\left(1.14 \mathrm{~g} \mathrm{~cm}^{-3}\right)$ and Px $\left(1.19 \mathrm{~g} \mathrm{~cm}^{-3}\right)$ soils; in the Lh soil the same sludge dose, in terms of $\mathrm{t} \mathrm{ha}^{-1}$, gave rise to a larger sludge/soil mass rate. The $\mathrm{pH}$ increase by almost one unit in the Lh soil following the addition of $320 \mathrm{t}$ of sludge ha-1 favoured the retention of metals, and therefore, the total average percentage of metal extracted was less than expected.

The global trends observed after applying a multifactorial ANOVA (Table 3) are depicted in detail in Figs. 3-5, which show the average concentrations of $\mathrm{Zn}, \mathrm{Pb}$ and $\mathrm{Cu}$ extracted in the Tessier fractions of soils following application rates of $0,80,160$ and $320 \mathrm{t} \mathrm{ha}^{-1}$. In comparison with the control soils, sewage sludge addition statistically increased $(P<0.05)$ the concentration of $\mathrm{Zn}$ extracted by $\mathrm{NH}_{2} \mathrm{OH} . \mathrm{HCl}, \mathrm{NaOAc} / \mathrm{HOAc}$ and $\mathrm{H}_{2} \mathrm{O}_{2} / \mathrm{HNO}_{3}$ (Fig. 3); the largest increases took place in oxides. As the $\mathrm{Zn}$ was mostly oxide-bound in sewage sludge (Fig. 1), its application to the soils increased the percentage of the reducible fraction (Fig. 3). There was no significant change in the $\mathrm{Zn}$ content extracted from the residual fraction. Exchangeable $\mathrm{Zn}$ was detected only in soil-sludge mixtures from the acidic soil (Lh), and was always below $2.5 \%$ of the total extracted in the five fractions. In Px, Cx1 and Cx 2 soils immobilisation of the exchangeable $\mathrm{Zn}$ from sludge took place. It was attributed to the basic $\mathrm{pH}$ and the buffering capacity of soils as a consequence of the presence of calcium carbonate $(\mathrm{Px}$, $40 \%$; $\mathrm{Cx} 2,19 \%$; Cx 1, 6\%). On the contrary, acidity and the scarcity of carbonates in the Lh soil favoured the release of Zn from sludge (Parveen et al. 1994).

The only significant increase $(P<0.05)$ in the $\mathrm{Cu}$ concentration extracted following sludge application to soils corresponded to the fraction extracted by $\mathrm{H}_{2} \mathrm{O}_{2} / \mathrm{HNO}_{3}$ (Fig. 4); there were no significant differences in the concentration obtained in the $\mathrm{NH}_{2} \mathrm{OH} . \mathrm{HCl}$ and residual fractions. The copper profile reflected its distribution in the sludge and in the soils control $\left(0 \mathrm{t} \mathrm{ha}^{-1}\right)$, and no $\mathrm{Cu}$ redistribution was detected in the fractions. The organic matter contained by sewage sludge acts in soils both as a source of $\mathrm{Cu}$ but also as a major adsorbent for this metal; thus, the extraction and consequently the mobility of $\mathrm{Cu}$ was mainly controlled by organic matter (Planquart et al. 1999).

The main contribution of sludge to the partitioning of $\mathrm{Pb}$ was in the $\mathrm{H}_{2} \mathrm{O}_{2} / \mathrm{HNO}_{3}$ fraction (Fig. 5), as a consequence of both the association of $\mathrm{Pb}$ with that fraction in sludge (70.6\%) (Fig. 1), and the non existence of a redistribution of this metal. In Lh, Cx 1 and Px soils increases were statistically significant $(P<0.05)$ for doses more than $160 \mathrm{t} \mathrm{ha}^{-1}$; but in $\mathrm{Lh}$ soil they were significant only in $\mathrm{NH}_{2} \mathrm{OH} . \mathrm{HCl}$ fraction and for the maximum dose of $320 \mathrm{tha}^{-1}$. Nickel and 


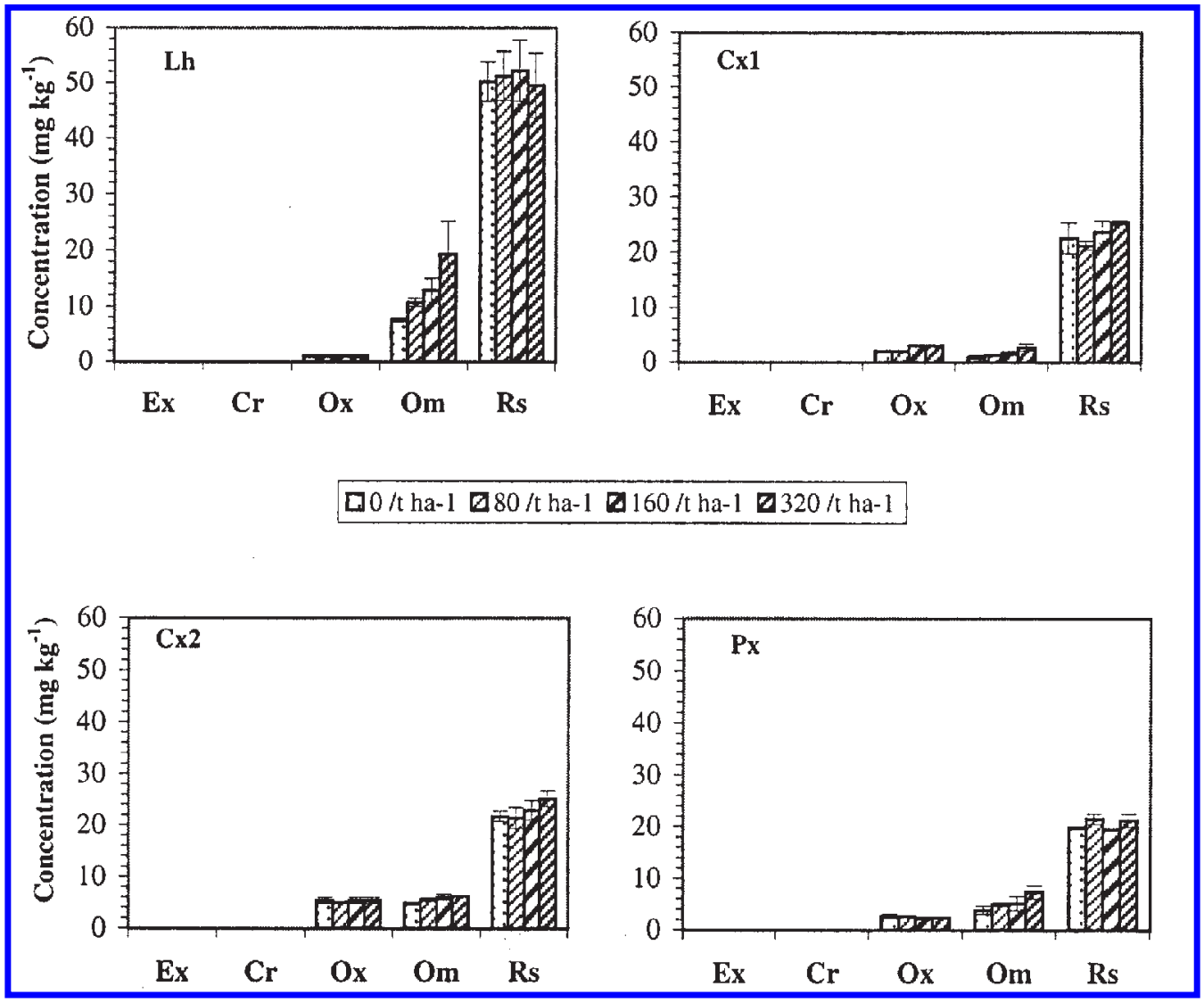

Fig. 4. Fractionation of $\mathrm{Cu}$ in the soils amended with sewage sludge $(0,80,160$ and $320 \mathrm{t} \mathrm{ha}^{-1}$ ). The results are the average concentration of three replicates and include the standard deviation. (Ex, exchangeable; $\mathrm{Cr}$, carbonates; $\mathrm{Ox}, \mathrm{Fe}$ and $\mathrm{Mn}$ oxides; Om, organic matter; Rs, residual).
Cd concentrations extracted in the Tessier partitioning did not significantly increase with the sewage sludge application rates.

\section{Effects of Sewage Sludge Application on Heavy Metal Extracted by EDTA and DTPA Solutions}

Metal concentrations extracted with EDTA and DTPA are expressed as percentages of the total concentrations to eliminate the effect of the different amount of metals in the sewage sludge, and to be able to screen both chelates for their ability to extract metals. Table 4 shows that the three analyzed variables, sewage sludge dose, soil, and metal contributed significantly to the total variance; however, the contribution varied with the extractants. With EDTA (pH, 4.65) the type of soil contributed to the total variance more than the metal type or sludge rate. The differences in the carbonate contents of soils (Table 1) would explain that the soils was the variable with the largest contribution to the total variance for EDTA extraction (Batley 1987; Singh et al. 1996). On the other hand, the extraction with DTPA (pH, 7.30), prepared to avoid soil carbonate dissolution (Lindsay and Norwell 1978), was more sensitive to metal type.

The mean percentages extracted with EDTA and DTPA for the different sludge doses are shown in Table 5. Each result is the average value obtained by a given metal in the four soils (metal subgroup) or by a given soil in the five metals (soil subgroup). The average percentages of $\mathrm{Cd}, \mathrm{Cu}, \mathrm{Ni}$,
$\mathrm{Pb}$ and $\mathrm{Zn}$ extracted with EDTA were approximately between 3 and 9 times larger than those obtained by DTPA, probably due to the higher concentration and lower $\mathrm{pH}$ of EDTA dissolution. In control soils $\left(0 \mathrm{t} \mathrm{ha}^{-1}\right)$, both extractants removed more $\mathrm{Pb}$ and $\mathrm{Cu}$ than $\mathrm{Cd}, \mathrm{Ni}$ or $\mathrm{Zn}$.

For all metals and soils, the percentages extracted increased with sewage sludge rates (Table 5). For both extractants, the largest increases corresponded to $\mathrm{Zn}$ followed by $\mathrm{Pb}$. For $\mathrm{Cd}, \mathrm{Cu}$ and $\mathrm{Ni}$ the difference between the percentages extracted at the highest rate and the control was below $2.6 \%$. Zinc was the metal with the largest concentration in the sewage sludge and it was also present in more mobile fractions than $\mathrm{Pb}$ and $\mathrm{Cu}$ (Fig. 1). Despite $\mathrm{Cu}$ concentration in sludge was 1.6 times larger than that of $\mathrm{Pb}$, the smaller increase in the percentage of extracted $\mathrm{Cu}$ reflected that $\mathrm{Cu}$ formed more stable complexes with sludge's organic matter than $\mathrm{Pb}$. The average percentages of $\mathrm{Cd}$ and $\mathrm{Ni}$ extracted with EDTA and DTPA increased slightly with increasing sewage sludge rates; this increment was not observed in the Tessier sequential partitioning. Consequently, both chelates seemed to be more effective to assess the mobility of metals added with the sludges at low concentrations than the Tessier's chemical partitioning.

The effectiveness of EDTA and DTPA to remove metals varied with soils. The average percentages extracted were lower in the acidic soil (Lh) than in calcareous soils (Table 5), probably because the complexing capacity of 

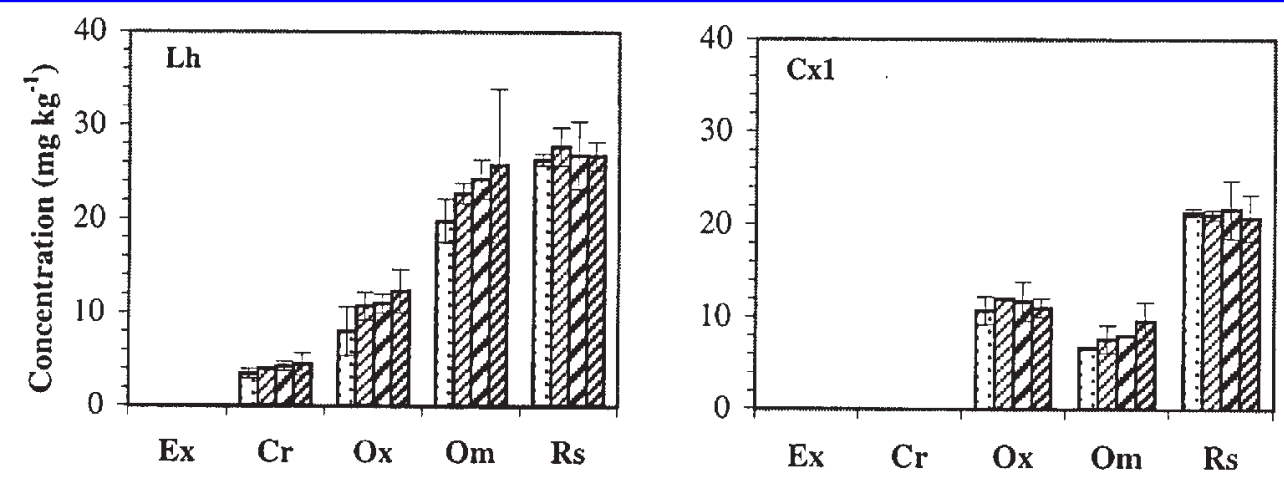

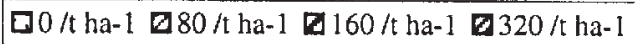
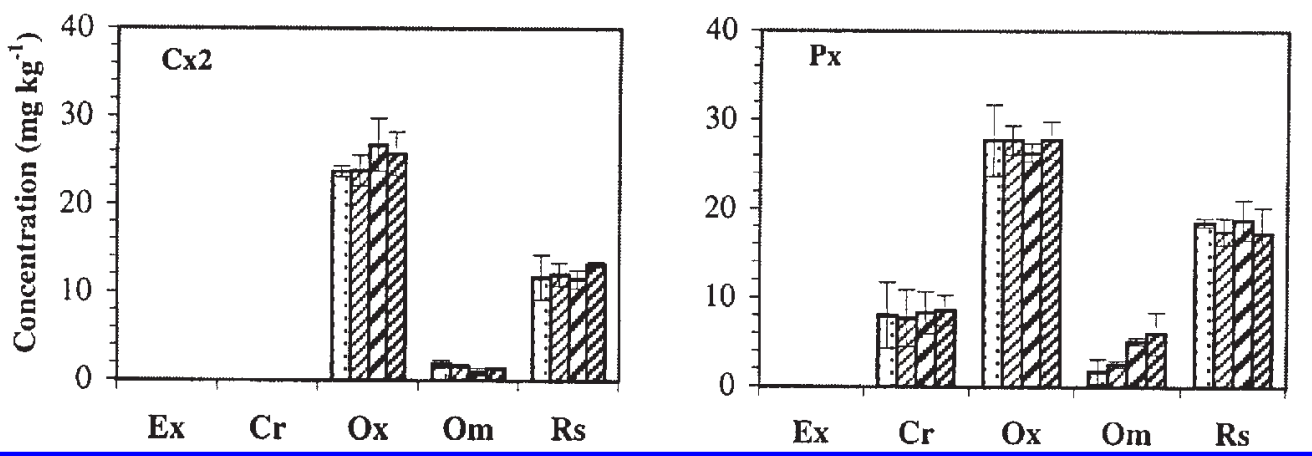

Fig. 5. Fractionation of $\mathrm{Pb}$ in the soils amended with sewage sludge $(0,80,160$ and $320 \mathrm{tha}^{-1}$ ). The results are the average concentration of three replicates and include the standard deviation. (Ex, exchangeable; $\mathrm{Cr}$, carbonates; $\mathrm{Ox}, \mathrm{Fe}$ and $\mathrm{Mn}$ oxides; Om, organic matter; Rs, residual).

Table 4. ANOVA multifactorial on the percentages of $\mathrm{Cd}, \mathrm{Cu}, \mathrm{Ni}, \mathrm{Pb}$ and $\mathrm{Zn}$ extracted with EDTA and DTPA in the soils ( $\mathrm{Lh}, \mathrm{Cx} 1, \mathrm{Cx} 2$ and Px) spiked with different doses of sewage sludge $(0,80,160$ and $320 \mathrm{t} \mathrm{ha}^{-1}$ )

\begin{tabular}{|c|c|c|c|c|c|}
\hline & $\begin{array}{l}\text { Sum of } \\
\text { squares }\end{array}$ & $\begin{array}{l}\text { Degrees of } \\
\text { freedom }\end{array}$ & $\begin{array}{l}\text { Mean } \\
\text { square }\end{array}$ & $F$ & $\begin{array}{c}\text { Probability } \\
\text { level }\end{array}$ \\
\hline & & & EDTA & & \\
\hline Soil & 9069 & 3 & 3023 & 498 & 0.000 \\
\hline Metal & 10007 & 4 & 2501 & 412 & 0.000 \\
\hline $\begin{array}{l}\text { Sewage sludge } \\
\text { doses }\end{array}$ & 1292 & 3 & 431 & 71 & 0.000 \\
\hline \multirow[t]{2}{*}{ Total } & 20368 & 10 & 2037 & 335 & 0.000 \\
\hline & & & DTPA & & \\
\hline Soil & 99 & 3 & 33 & 47 & 0.000 \\
\hline Metal & 1351 & 4 & 338 & 484 & 0.000 \\
\hline $\begin{array}{l}\text { Sewage sludge } \\
\text { doses }\end{array}$ & 168 & 3 & 56 & 80 & 0.000 \\
\hline Total & 1618 & 10 & 162 & 232 & 0.000 \\
\hline
\end{tabular}

EDTA and DTPA is not favoured at acidic $\mathrm{pH}$ (Harris 1992). In all soils, average percentages extracted increased with sludge doses. The squared correlation coefficients for the EDTA extraction ranged from 0.97 for $\mathrm{Cx} 2$ to 0.70 for Px; and for the DTPA extraction, the coefficients varied between 0.97 for $\mathrm{Lh}$ soil and 0.64 for $\mathrm{Cx} 1$. The soil with the largest percentage of carbonates $(\mathrm{Px})$ showed the smallest increment in the metal extracted with increasing sludge
Table 5. Mean percentages of metals extracted with EDTA and DTPA for different sludge doses

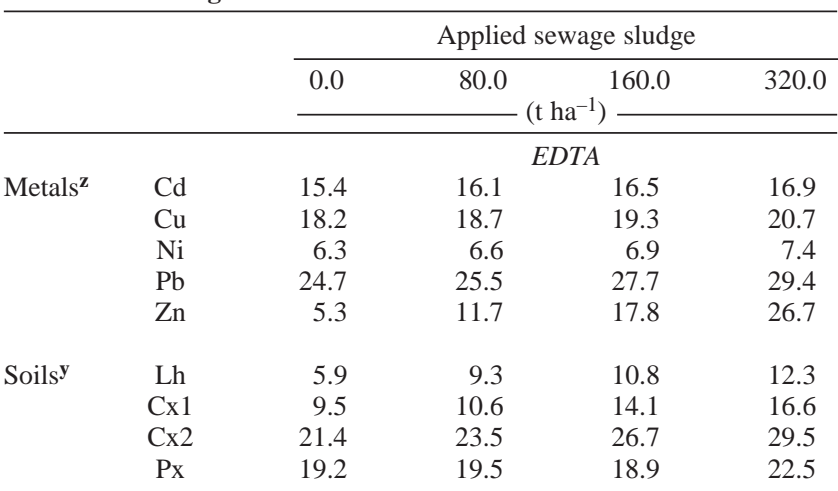

\begin{tabular}{lccccc} 
Metals $^{\mathbf{z}}$ & $\mathrm{Cd}$ & 1.9 & 2.4 & 2.4 & 2.8 \\
& $\mathrm{Cu}$ & 7.1 & 7.2 & 7.7 & 7.5 \\
& $\mathrm{Ni}$ & 0.7 & 0.8 & 1.1 & 1.4 \\
& $\mathrm{~Pb}$ & 5.2 & 5.6 & 6.7 & 6.8 \\
& $\mathrm{Zn}$ & 1.7 & 4.2 & 6.4 & 9.1 \\
& & & & & \\
Soils $^{\mathbf{y}}$ & $\mathrm{Lh}$ & 2.0 & 3.5 & 3.9 & 5.8 \\
& $\mathrm{Cx} 1$ & 3.2 & 4.1 & 4.9 & 4.7 \\
& $\mathrm{Cx} 2$ & 3.3 & 3.7 & 4.5 & 5.5 \\
& $\mathrm{Px}$ & 4.8 & 4.9 & 6.3 & 6.1 \\
\hline
\end{tabular}

${ }^{\mathrm{z}}$ Average percentages extracted including all soils.

${ }^{\mathbf{y}}$ Average percentages extracted including all metals. 
doses, and was largely attributable to buffering soil $\mathrm{pH}$ in basic soils (McBride 1995).

To sum up, the Tessier partitioning of $\mathrm{Cd}, \mathrm{Cu}, \mathrm{Ni}, \mathrm{Pb}$ and $\mathrm{Zn}$ in the sewage sludge reflected the predominance of the $\mathrm{NH}_{2} \mathrm{OH} . \mathrm{HCl}$ and $\mathrm{H}_{2} \mathrm{O}_{2} / \mathrm{HNO}_{3}$ extracted metals. Soil amendment with sewage sludge increased the total concentration of $\mathrm{Cu}, \mathrm{Pb}$ and $\mathrm{Zn}$. There were no significant differences in the total concentration of $\mathrm{Ni}$ and $\mathrm{Cd}$ after the addition of sludge. The rise mirrored the sludge metallic content and the applied doses. A positive correlation was detected between a higher sludge application rate and the overall mean percentage of metals extracted in non residual fractions. In the acidic soil, exchangeable $\mathrm{Zn}$ was detected in all soil-sludge mixtures; in calcareous soils, immobilisation of exchangeable $\mathrm{Zn}$ from sludge took place. Extraction with EDTA was more sensitive to soil type, whereas extraction with DTPA showed wider variation with metals. Both chelates seemed to be more effective to assess the mobility of metals added with the sludges at low concentrations than the Tessier's chemical partitioning. The Tessier procedure, much more laborious than selective extractions, showed significant differences only in the extractions with $\mathrm{NH}_{2} \mathrm{OH} . \mathrm{HCl}$ and $\mathrm{H}_{2} \mathrm{O}_{2} / \mathrm{HNO}_{3}$.

\section{ACKNOWLEDGEMENTS}

This work was supported by a project of Instituto Nacional de Investigación y Tecnología Agraria y Alimentación (INIA SC94-026).

Adriano, D. C. 1986. Trace elements in the terrestrial environment. Springer-Verlag, New York, NY.

Alloway, B. J. 1990. Soil processes and the behaviour of metals. Pages 7-28 in B. J. Alloway, ed. Heavy metals in soils. John Wiley and Sons, New York, NY.

Alloway, B. J. 1995. The origins of heavy metals in soils. Pages 38-57 in B. J. Alloway, ed. Heavy metals in soils. Blackie Academic and Professional, London, UK.

Alloway, B. J. and Jackson, A. P. 1991. The behavior of heavy metals in sewage sludge-amended soils. Sci. Total Environ. 100: $151-176$.

Batley, C. E. 1987. Heavy metal speciation in waters, sediments and biota from lake Macqarie, NSW. Austral. J. Mar. Freshw. Res. 38: 591-606.

Boletín Oficial del Estado 1990. Madrid. 262: 32, 339-40.

Brümer, G. W. 1986. Heavy metal species, mobility and availability in soils. Pages 169-192 in M. Bernhard, F. E. Brinckman, and P. J. Sadler, eds. The importance of chemical Aspeciation@ in environmental processes. Springer-Verlag, New York, NY.

Community European Council. 1986. Council Directive of 12 June 1986 on the protection of the environment, and in particular of the soil, when sewage sludge is used in agriculture (86/278/EEC). Official J. Eur. Communities, No. L 181/ 6-12.

Dudka, S. and Chlopecka, A. 1990. Effect of solid-phase speciation on metal mobility and phytoavailability in sludge-amended soil. Water Air Soil Pollut. 51: 153-160.

Echeverría, J. C., Morera, M. T., Mazkiarán, M. C. and Garrido, J. J. 1998. Competitive sorption of heavy metal by soils. Isotherms and fractional factorial experiments. Environ. Pollut. 101: 275-284.

Echeverría, J. C., Morera, M. T. and Garrido, J. J. 1999a. Metal-induced chromium(VI) sorption by two calcareous soils. Aust. J. Soil Res. 37: 431-443.
Echeverría, J. C., Morera, M. T., Mazkiarán, M. C. and Garrido, J. J. 1999b. Characterization of the porous structure of soils. Adsorption of nitrogen $(77 \mathrm{~K})$ and carbon dioxide $(273 \mathrm{~K})$, and mercury porosimetry. Eur. J. Soil Sci. 50: 497-503.

Emmerich, W. E., Lund, L. J., Page, A. L. and Chang, A. C. 1982. Solid phase forms of heavy metals in sewage sludge-treated soils. J. Environ. Qual. 11: 178-181.

Harris, D. C. 1992. Análisis Químico Cuantitativo; Editorial Iberoamericana, Mejico.

Harrison, R. M. 1981. Chemical association of lead, $\mathrm{Cd}, \mathrm{Cu}$ and $\mathrm{Zn}$ in street dusts and roadside soils. Environ. Sci. Technol. 15: 1378-1383.

Heckman, J. R., Angle, J. S. and Chaney, R. L. 1987. Residual effect of sewage sludge on soybeans: I. Accumulation of heavy metals. J. Environ. Qual. 16: 113-117.

Jackson, M. L. 1982. Análisis Químico de suelos. 2nd ed. Omega, Barcelona, Spain.

Juste, C. and Tauzin, J. 1992. Comparison of the bioavailability of cadmium present in various fertilizers. C.R. Acad. Agr. France 78: 71-79.

Kabata-Pendias, A. and Pendias, H. 1993. Trace elements in soils and plants. 4nd ed. CRC Press, Boca Raton, FL.

Kiekens, L. 1984. Behaviour of heavy metals in soils. Pages 126-134 in S. Berglund, R. D. Davis and P. L' Hermite, eds. Utilization of sewage sludge on land: rates of application and longterm effects of metals. D. Reidel, Dordrecht, The Netherlands.

Kim, N. D. and Fergusson, J. E. 1991. Effectiveness of a commonly used sequential extraction technique in determining the speciation of cadmium in soils. Sci. Total Environ. 105: 191-209.

Kuo, S. 1990. Cadmium buffering capacity and accumulation in Swiss chard in some sludge-amended soils. Soil Sci. Soc. Am. J. 54: 86-91.

Lakanen, E. and Erviö, R. 1971. A comparison of eight extractants for the determination of plant available micronutrients in soils. Acta Agric. Fenn. 123: 223-232.

Lebourg, A., Sterckeman, T., Ciesielski, H. and Proix, N. 1996. Intérêt de différents réactifs d'extraction chimique pour l'évaluation de la biodisponibilité des métaux en traces du sol. Agronomie 16: 201-215.

Lindsay, W. L. and Norvell, W. A. 1978. Development of a DTPA soil test for zinc, iron, manganese, and copper. Soil Sci. Soc. Am. J. 42: 421-428.

Loeppert, R. H., Hallmark, C. T. and Koshy, M. M. 1984. Routine procedure for rapid determination of soil carbonates. Soil Sci. Soc. Am. J. 48: 1030-1033.

Martin, J. M., Nirel, P. and Thomas, A. J. 1987. Sequential extraction techniques: promises and problems. Mar. Chem. 22: 313-341.

McBride, M. B. 1995. Toxic metal accumulation from agricultural use of sludge: Are USEPA regulations protective? J. Environ. Qual. 24: 5-18.

McGrath, S. P. and Cegarra, J. 1992. Chemical extractability of heavy metals during and after long-term applications of sewage sludge to soils. J. Soil Sci. 43: 313-321.

McLean, E. O. 1982. Soil $\mathrm{pH}$ and lime requirement. Pages 199-224 in A. L. Page, R. H. Miller, and D. R. Keeney, eds. Methods of soil analysis. Part 2. Chemical and microbiological properties. 2nd ed. SSSA, Madison, WI.

Narwal, R. P. and Singh, B. R. 1998. Effect of organic materials on partitioning extractability and plant uptake of metals in an alum shale soil. Water Air Soil Pollut. 103: 405-421.

Obrador, A., Rico, M. I., Alvarez, J. M. and Mingot, J. 1998. Mobility and extractability of heavy metals in contaminated sewage sludge-soil incubated mixtures. Environ. Technol. 19: 307-314. 
Parveen, Z., Edwards, A. C. and Cresser, M. S. 1994. Redistribution of zinc from sewage sludge applied to a range of contrasting soils. Sci. Total Environ. 155: 161-171.

Pengxing, W., Erfu, Q., Zhenbin, L. and Shuman, L. M. 1997. Fractions and availability of nickel in loessial soil amended with sewage or sewage sludge. J. Environ. Qual. 26: 795-801.

Petruzzelli, G. 1989. Recycling wastes in agriculture: heavy metal bioavailability. Agric. Ecosyst. Environ., 27: 493-503.

Petruzzelli, G., Ottaviani, M., Lubrano, L. and Veschetti, E. 1994. Characterization of heavy metals mobile species in sewage sludge for agricultural utilization. Agrochimica 38: 277-284.

Pickering, W. F. 1986. Metal ion speciation - Soils and sediments. A review. Ore Geol. Rev. 1: 83-146.

Planquart, P., Bonin, G., Prone, A. and Massiani, C. 1999. Distribution, movement and plant availability of trace metals in soils amended with sewage sludge composts: application to low metal loadings. Sci. Total Environ. 241: 161-179.

Primo Yúfera, E. and Carrasco Dorriens, J. M. 1987. Química Agrícola. Alhambra, Madrid, Spain.

Shuman, L. M. 1991. Chemical forms of micronutrients in soils. Pages 113-144 in J. J. Mortvedt, F. R. Cox, L. H. Shuman, and R. H. Welch, eds. Micronutrients in agriculture. 2nd ed. SSSA, Madison, WI.

Sims, J. T. and Kline, J. S. 1991. Chemical fractionation and plant uptake of heavy metals in soils amended with co-composted sewage sludge. J. Environ. Qual. 20: 387-395.
Singh, S. P., Tack, F. M. G. and Verloo, M. G. 1996. Solid-phase distribution of heavy metals as affected by single reagent extraction in dredged sediment derived surface soils. Chem. Speciation Bioavailability 8: 37-43.

Soil Survey Staff. 1975. Soil taxonomy: a basic system of soil classification for making and interpreting soil surveys. US Government Printing Office, Washington, WA.

Tan, K. H. 1982. Principles of soil chemistry. Marcel Dekker, New York, NY.

Taylor, R., Xiu, H., Mehadi, A., Shuford, J. and Tadesse, W. 1995. Fractionation of residual cadmium, copper, nickel, lead and zinc in previously sludge-amended soil. Commun. Soil Sci. Plant Anal. 26: 2193-2204.

Tessier, A., Campbell, P. G. C. and Bisson, M. 1979. Sequential extraction procedure for the speciation of particulate trace metals. Anal. Chem. 51: 844-851.

Tsadilas, C. D., Matsi, T., Baarbayiannis, N. and Dimoyiannis, D. 1995. Influence of sewage sludge application on soil properties and on distribution and availability of heavy metal fractions. Commun. Soil Sci. Plant Anal. 26: 2603-2619.

Winer, B. J., Brown, D. R. and Michels, J. M. 1991. Statistical principles in experimental design. 3rd ed. McGraw Hill, New York, NY.

Xian, X. F. and Shokohifard, G. I. 1989. Effect of pH on chemical forms and plant availability of cadmium, zinc, and lead in polluted soils. Water Air Soil Pollut. 45: 265-273. 


\section{This article has been cited by:}

1. K. R. Islam, S. Ahsan, K. Barik, E. L. Aksakal. 2013. Biosolid Impact on Heavy Metal Accumulation and Lability in Soiln Under Alternate-Year No-Till Corn-Soybean Rotation. Water, Air, \& Soil Pollution 224:3. . [CrossRef]

2. T. K. Pandit, S. K. Naik, P. K. Patra, D. K. Das. 2012. Influence of Lime and Organic Matter on the Mobility of Cadmium in Cadmium-Contaminated Soil in Relation to Nutrition of Spinach. Soil and Sediment Contamination: An International Journal 21:4, 419-433. [CrossRef]

3. Ahmed M. Donia, Asem A. Atia, Rama T. Rashad. 2011. Fast removal of Cu(II) and $\mathrm{Hg}$ (II) from aqueous solutions using kaolinite containing glycidyl methacrylate resin. Desalination and Water Treatment 30:1-3, 254-265. [CrossRef]

4. S. Kamali, A. Ronaghi, N. Karimian. 2011. Soil Zinc Transformations as Affected by Applied Zinc and Organic Materials. Communications in Soil Science and Plant Analysis 42:9, 1038-1049. [CrossRef]

5. Sudarshana Sharma, Parmanand Sharma, A. K. Bhattacharyya. 2010. Accumulation of Heavy Metals in Wheat (Triticum aestivum L.) Seedlings Grown in Soils Amended with Electroplating Industrial Sludge. Communications in Soil Science and Plant Analysis 41:21, 2505-2516. [CrossRef]

6. S. Kamali, A. Ronaghi, N. Karimian. 2010. Zinc Transformation in a Calcareous Soil as Affected by Applied Zinc Sulfate, Vermicompost, and Incubation Time. Communications in Soil Science and Plant Analysis 41:19, 2318-2329. [CrossRef]

7. Geeta Tewari, Lalit M. Tewari, Prakash Chandra Srivastava, Bali Ram. 2009. Chemical transformation of copper in some sludgeamended soils. Archives of Agronomy and Soil Science 55:4, 415-427. [CrossRef]

8. Silvana Irene Torri, Raúl Lavado. 2008. Zinc distribution in soils amended with different kinds of sewage sludge. Journal of Environmental Management 88:4, 1571-1579. [CrossRef]

9. D. Gavalda, J.D. Scheiner, J.C. Revel, G. Merlina, M. Kaemmerer, E. Pinelli, M. Guiresse. 2005. Agronomic and environmental impacts of a single application of heat-dried sludge on an Alfisol. Science of The Total Environment 343:1-3, 97-109. [CrossRef]

10. Saleh Kaoser, Suzelle Barrington, Maria Elektorowicz, Li Wang. 2004. Copper Adsorption with Pb and Cd in Sand-Bentonite Liners under Various pHs. Part II. Effect on Adsorption Sites. Journal of Environmental Science and Health, Part A 39:9, $2241-2255$. [CrossRef] 